Article

\title{
Selina-1,3,7(11)-trien-8-one and \\ Oxidoselina-1,3,7(11)-trien-8-one from Eugenia uniflora Leaf Essential Oil and Their Cytotoxic Effects on Human Cell Lines
}

\author{
Jociani Ascari ${ }^{1, *}$, Marcos Felipe Maciel Pereira ${ }^{1}$, Vinicius Monteiro Schaffka ${ }^{2}$, Domingos Sávio Nunes ${ }^{2}$, \\ Cássia Gonçalves Magalhães ${ }^{2} \mathbb{D}$, Jânio Sousa Santos ${ }^{2}$, Daniel Granato ${ }^{3, *} \mathbb{C}$, Mariana Araújo Vieira do Carmo ${ }^{4}$, \\ Luciana Azevedo ${ }^{4}$, Marcos Vinicio Lopes Rodrigues Archilha ${ }^{5}$ and Dilamara Riva Scharf ${ }^{6}$
}

Citation: Ascari, J.; Felipe Maciel Pereira, M.; Schaffka, V.M.; Nunes, D.S.; Magalhães, C.G.; Santos, J.S.; Granato, D.; Carmo, M.A.V.d.; Azevedo, L.; Archilha, M.V.L.R.; et al. Selina-1,3,7(11)-trien-8-one and Oxidoselina-1,3,7(11)-trien-8-one from Eugenia uniflora Leaf Essential Oil and Their Cytotoxic Effects on Human Cell Lines. Molecules 2021, 26, 740. https://doi.org/10.3390/ molecules 26030740

Academic Editor: Daniela Rigano

Received: 19 December 2020

Accepted: 25 January 2021

Published: 31 January 2021

Publisher's Note: MDPI stays neutral with regard to jurisdictional claims in published maps and institutional affiliations.

Copyright: (c) 2021 by the authors. Licensee MDPI, Basel, Switzerland. This article is an open access article distributed under the terms and conditions of the Creative Commons Attribution (CC BY) license (https:/ / creativecommons.org/licenses/by/ $4.0 /)$.
1 Department of Biology, Federal Technological University of Paraná, 85892-000 Santa Helena, PR, Brazil; marcosfmpereira@gmail.com

2 Department of Chemistry, State University of Ponta Grossa, 84030-900 Ponta Grossa, PR, Brazil; vschaffka@gmail.com (V.M.S.); senunsd@gmail.com (D.S.N.); cassiagmag@yahoo.com.br (C.G.M.); santosjs.food@gmail.com (J.S.S.)

3 Food Processing and Quality, Natural Resources Institute Finland (Luke), FI-02150 Espoo, Finland

4 Nutrition Faculty, Federal University of Alfenas, 37130-000 Alfenas, MG, Brazil; marianavieira06@hotmail.com (M.A.V.d.C.); lucianaazevedo2010@gmail.com (L.A.)

5 Institute of Chemistry, University of São Paulo, 05508-000 São Paulo, SP, Brazil; archilha@iq.usp.br

6 Department of Chemical Engineering, Regional University of Blumenau Foundation, 89030-000 Blumenau, SC, Brazil; driva@furb.br

* Correspondence: jascari@utfpr.edu.br (J.A.); granatod@gmail.com (D.G.)

\begin{abstract}
The sesquiterpenes selina-1,3,7(11)-trien-8-one and oxidoselina-1,3,7(11)-trien-8-one were isolated from the essential oil of Eugenia uniflora L. leaves. The structures were elucidated using spectrometric methods (UV, GC-MS, NMR, and specific optical rotation). The relationship between antioxidant activity, as determined by DPPH assay, and the cytotoxic effect was evaluated using tumor cells, namely lung adenocarcinoma epithelial cells (A549) and human hepatoma carcinoma cells (HepG2), as well as a model of normal human lung fibroblast cells (IMR90). Both compounds did not show prominent free-radical scavenging activity according to DPPH assay, and did not inhibit lipid peroxidation in Wistar rat brain homogenate. The isolated compounds showed pro-oxidative effects and cytotoxicity in relation to the IMR90 cell line.
\end{abstract}

Keywords: Eugenia uniflora; selina-1,3,7(11)-trien-8-one; oxidoselina-1,3,7(11)-trien-8-one; cytotoxicity

\section{Introduction}

Eugenia uniflora L. (Myrtaceae), popularly known in Brazil as pitangueira, is a small tree species widely distributed in South and Central America [1,2]. In view of the pharmacological activities attributed to the species in folk medicine, the plant has received intense scientific attention and become of interest to the cosmetic industry [3-5]. E. uniflora currently has at least 41 recognized and registered heterotypic synonyms in Brazil [6], which indicates the existence of a large number of varieties for this plant species.

In the first isolation reports of volatile compounds from E. uniflora leaves, some volatile sesquiterpenes were obtained, such as furanodiene, isofuranoelemene, curzerene, germacrene B, $\gamma$-elemene, selina-4(14),7(11)-diene, $\beta$-elemene, caryophyllene, germacrene $D$, bicyclogermacrene, $\beta$-selinene, atractylone, germacrone, selina-1,3,7(11)-trien-8-one (1), and oxidoselina-1,3,7(11)-trien-8-one (2) [7,8]. Most of these mentioned sesquiterpenes are also known as volatile components of various plant species from other botanical families, especially from the Zingiberaceae (Curcuma), Burseraceae (Commiphora), and Apiaceae (Smyrnium) [9-13]. To date, the sesquiterpenes selina-1,3,7(11)-trien-8-one (1) and oxidoselina-1,3,7(11)-trien-8-one (2) (Figure 1) have been found solely in E. uniflora. 

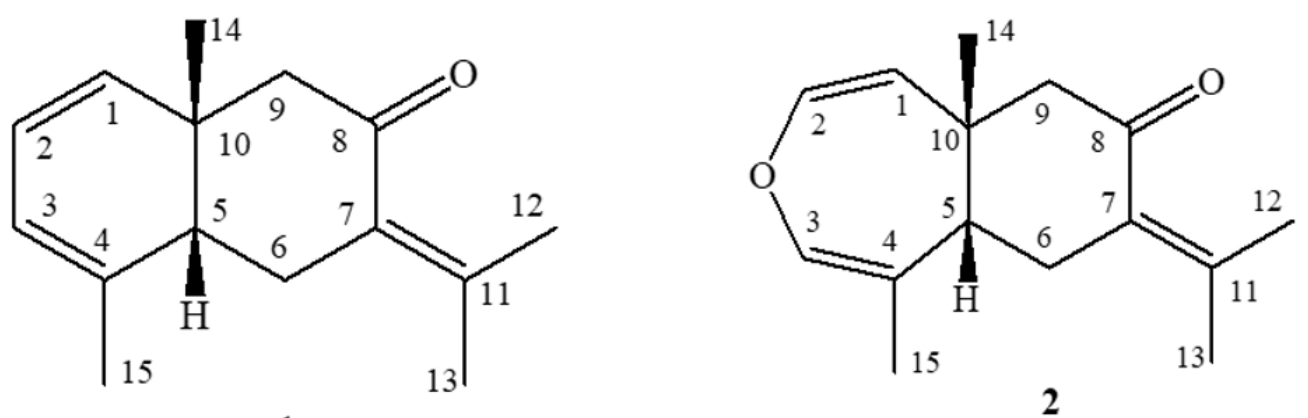

1

Figure 1. Chemical structures of selina-1,3,7(11)-trien-8-one (1) and oxidoselina-1,3,7-trien-8-one (2) presenting the relative stereochemistry in C-5 and C-10, as proposed in the literature [8].

Studies on the chemical composition of essential oils from E. uniflora leaves show that compounds $\mathbf{1}$ and $\mathbf{2}$ are not thermosensitive, but some other components can undergo Cope rearrangement transformations during gas chromatography analysis, a method that is proven to be especially inadequate for the analysis of sesquiterpenes such as furanodiene, curzerene, germacrene $B, \gamma$-elemene, germacrone, and $\beta$-elemenone $[7,8]$. This analytical aspect requires attention when interpreting the results of numerous publications on the chemical composition and biological activities of essential oils.

The chemical composition of the volatiles obtained from different $E$. uniflora chemotypes shows they are sesquiterpenoids, including compounds $\mathbf{1}$ and $\mathbf{2}$, germacrenes A, B, and $\mathrm{D}$, germacrone, caryophyllene, atractylone, curzerene, and furanodiene, with some of these having been cited as chemical markers for the species [9-12].

Several studies have shown the potential biological activities of E. uniflora essential oils. Costa (2010) demonstrated the antifungal activity of essential oils from E. uniflora leaves against Paracoccidioides brasiliensis for samples presenting curzerene, germacrene $\mathrm{D}$, and germacrene A as the major GC constituents [10]. An essential oil from the leaves of E. uniflora, containing $\mathbf{1}$ and $\mathbf{2}$ as the major compounds, showed antifungal activity against standard strains of Candida albicans, C. krusei, and C. tropicalis [13]. Additionally, another essential oil from E. uniflora leaves presenting curzerene and high proportions of $\mathbf{1}$ and $\mathbf{2}$ according to GC analyses showed relevant hepatoprotective activity, and the therapeutic potential of both compounds for the development of herbal medicines was mentioned [14,15].

Studies evaluating the cytotoxic action of E. uniflora essential oils on cancer cell lines have shown promising results. Ogunwande (2005) demonstrated that an essential oil presenting the sesquiterpene $\mathbf{1}$, curzerene, atractylone, and furanodiene has cytotoxic and antiproliferative effects in relation to prostatic carcinoma cells (PC-3), hepatocellular carcinoma cells (HepG2), and breast ductal carcinoma cells (578T) [16]. Figueiredo (2019) evaluated the cytotoxic effects of E. uniflora oils and curzerene in relation to human colon (HCT-116), gastric (AGP-01), melanoma (SKMEL-19), and normal human fibroblast (MRC5) cell lines. Curzerene showed more significant activity against SKMEL-19 cells, with oil samples that contained $\mathbf{1}$ and $\mathbf{2}$ in addition to curzerene, germacrene B, caryophyllene oxide, caryophyllene, $\beta$-elemene, and $\gamma$-elemene as the major compounds showing cytotoxic activity against all cell lines [12].

Given the importance of volatile compounds as bioactive natural products from medicinal and food plants along with the need to track their different biological activities, two sesquiterpenes from the leaves of E. uniflora, selina-1,3,7-trien-8-one (1) and oxidoselina-1,3,7(11)-trien-8-one (2), were isolated using conventional column chromatography. Structural elucidation was performed using modern spectroscopy and specific optical rotation techniques. We also present, here, the results of antioxidant analyses for the two sesquiterpenes and an assessment of the relationship between antioxidant power and cytotoxic effects in different normal and cancerous human cells. 


\section{Results and Discussion}

The chemical composition found in this work for the E. uniflora leaf oil is shown in Table 1. The sample of the essential oil studied here presents the striking profile of one of the best known chemotypes of this plant species [14-18], in which the four main components stand out, namely curzerene, germacrene B, and $\mathbf{1}$ and 2 . In fact, the GC-MS analytical chromatogram of the essential oil obtained in the present work is even very similar to that obtained from leaves of the tree cultivated in Nigeria, which were used in a chemical study by Weyerstahl (1988) [8].

Table 1. Relative composition (\%) of the identified components in the GC-MS analysis of the essential oil from leaves of E. uniflora.

\begin{tabular}{|c|c|c|c|c|}
\hline $\mathbf{R}_{\mathrm{t}}(\min )$ & $\%$ & RRI $^{a}$ & RRI $^{b}$ & Compound Name \\
\hline 28.015 & 3.60 & 1392.8 & 1392 & $\beta$-elemene \\
\hline 29.174 & 0.98 & 1419.9 & 1420 & caryophyllene \\
\hline 29.760 & 0.83 & 1434.7 & 1434 & $\gamma$-elemene \\
\hline 31.942 & 0.11 & 1482.5 & 1480 & germacrene D \\
\hline 32.306 & 0.81 & 1493.8 & - & $M+204$ \\
\hline 32.404 & 4.72 & 1499.2 & 1500 & curzerene \\
\hline 34.764 & 1.74 & 1562.5 & 1561 & germacrene B \\
\hline 35.596 & 9.27 & 1580.3 & 1578 & spathulenol \\
\hline 35.809 & 6.66 & 1586.4 & 1588 & epiglobulol \\
\hline 36.131 & 1.22 & 1594.5 & - & $M+222$ \\
\hline 37.639 & 13.34 & 1632.1 & 1631 & $\begin{array}{c}\text { selina-3,5,7(11)- } \\
\text { trien-8-one } \\
(\mathbf{1})\end{array}$ \\
\hline 38.505 & 2.62 & 1658.5 & 1658 & selina-6-en-4-ol \\
\hline 39.661 & 1.27 & 1667.9 & 1666 & furanodiene \\
\hline 40.025 & 2.92 & 1696.6 & 1693 & germacrone \\
\hline 40.031 & 4.62 & 1700.1 & - & $M+232$ \\
\hline 40.824 & 3.58 & 1722.1 & - & $\begin{array}{c}M+220 \\
\text { oxidoselina- }\end{array}$ \\
\hline 41.821 & 20.44 & 1755.8 & 1757 & $\begin{array}{c}\text { 1,3,7(11)-trien-8-one } \\
\text { (2) }\end{array}$ \\
\hline 42.505 & 1.92 & 1769.9 & - & $M+220$ \\
\hline 42.612 & 2.20 & 1772.4 & - & $M+220$ \\
\hline 43.509 & 1.08 & 1797.5 & - & $M+218$ \\
\hline
\end{tabular}

RRI $^{\mathrm{a}}$ : values of calculated relative retention indices using the column Rtx-5MS (GC-MS) and the n-alkanes series $\mathrm{C} 8-\mathrm{C} 19 ; \mathrm{RRI}^{\mathrm{b}}{ }^{\text {: }}$ published relative retention indices for apolar columns $[17,18]$.

Chemical transformations of several of the components of the E. uniflora leaf essential oil are known to be caused by the heating conditions commonly used in GC-MS analysis, and a cold method analysis is required for correct composition evaluation $[7,8]$. Particularly important for the case of the sample described in the present research are the transformations of germacrene B into $\gamma$-elemene, furanediene into curzerene, and germacrone into $\beta$-elemenone, noting that compounds $\mathbf{1}$ and $\mathbf{2}$ are stable under the heating conditions used in GC-MS.

Weyerstahl and collaborators (1988) first isolated and identified compounds $\mathbf{1}$ and 2 as the major components of the essential oil, and during the decades that followed, these sesquiterpenes were found to also occur in various E. uniflora chemotypes [8-12]. Compound 1 was isolated in our laboratory as an oil and presented optical activity $[\alpha]_{D}^{20}-$ $8^{\circ}\left(c 1.0, \mathrm{CHCl}_{3}\right)$, very close to the value registered in the literature when the compound was isolated for the first time [8]. Compound 1, obtained by synthesis, presented the value of $[\alpha]_{D}^{20}-258^{\circ}\left(c 1.0, \mathrm{CHCl}_{3}\right)$ [19], which can be now considered as a very discrepant value when compared to that found for the natural substance.

The ${ }^{1} \mathrm{H}$ and ${ }^{13} \mathrm{C}$ NMR signals of $\mathbf{1}$ (see Table 2) were assigned based on thorough analysis of COSY, HSQC, and HMBC spectra presented in the Supplementary Materials. 
The ${ }^{1} \mathrm{H}$ NMR spectrum showed signals at $\delta_{\mathrm{H}} 2.47(\mathrm{~d}, J=14.5 \mathrm{~Hz})$ and $\delta_{\mathrm{H}} 2.30(\mathrm{~d}, J=14.5 \mathrm{~Hz})$ referring to diastereotopic hydrogens $\mathrm{H}-9$ and $\mathrm{H}_{-} 9^{\prime}$. At $\delta_{\mathrm{H}} 5.76(\mathrm{dd}, J=9.4,5.3 \mathrm{~Hz})$, a double doublet signal corresponds to the methynic hydrogen $\mathrm{H}-2$. Four methyl groups were observed with displacements at $\delta_{\mathrm{H}} 1.79(\mathrm{~s}, \mathrm{H}-12$ or $\mathrm{H}-13), \delta_{\mathrm{H}} 1.94(\mathrm{~d}, J=1.6 \mathrm{~Hz}, \mathrm{H}-12$ or $\mathrm{H}-13), \delta_{\mathrm{H}} 1.04(\mathrm{~s}, \mathrm{H}-14)$, and at $\delta_{\mathrm{H}} 1.85$ (s, H-15).

Table 2. ${ }^{1} \mathrm{H}$ and ${ }^{13} \mathrm{C}$ NMR spectra data for $\mathbf{1}$ and $\mathbf{2}$ isolated from the essential oil of E. uniflora.

\begin{tabular}{ccccc}
\hline \multirow{2}{*}{ H/C } & \multicolumn{2}{c}{$\mathbf{1}$} & \multicolumn{2}{c}{2} \\
\cline { 2 - 5 } & $\delta_{\mathbf{H}}(\boldsymbol{J ~ H z})$ & $\delta_{\mathbf{C}}$ & $\delta_{\mathbf{H}}(\boldsymbol{J ~ H z})$ & $\delta_{\mathbf{C}}$ \\
\hline 1 & $5.63(\mathrm{~d}, 5.2)$ & 131.7 & $4.41(\mathrm{~d}, 6.5)$ & 110.4 \\
2 & $5.76(\mathrm{dd}, 9.4,5.3)$ & 123 & $6.02(\mathrm{~d}, 7.7)$ & 140.6 \\
3 & $5.33(\mathrm{~d}, 9.4)$ & 118 & $6.13(\mathrm{~s})$ & 137.8 \\
4 & - & 138.3 & - & 119.1 \\
5 & $2.00(\mathrm{dd}, 10.6,4.8)$ & 46.1 & $2.21(\mathrm{dd}, 12.9,6.3)$ & 50.9 \\
6 & $2.66(\mathrm{dd}, 10.6,4.8)$ & 29.8 & $2.83(\mathrm{dd}, 15.4,4.8)$ & 32.9 \\
$6^{\prime}$ & $2.24(\mathrm{~m})$ & 29.8 & $2.44-2.54(\mathrm{~m})$ & 32.9 \\
7 & - & 132.6 & - & 130.7 \\
8 & - & 203.9 & - & 202.7 \\
9 & $2.47(\mathrm{~d}, 14.5)$ & 53.4 & $2.40(\mathrm{~d}, 15.0)$ & 57.8 \\
$9^{\prime}$ & $2.30(\mathrm{~d}, 14.5)$ & 53.4 & $2.19(\mathrm{~d}, 13.7)$ & 57.8 \\
10 & - & 38.5 & - & 41 \\
11 & - & 139.6 & - & 143.6 \\
12 or 13 & $1.79(\mathrm{~s})$ & 21.7 & $1.80(\mathrm{~s})$ & 22.3 \\
12 or 13 & $1.94(\mathrm{~d}, 1.6)$ & 22.6 & $1.98(\mathrm{~d}, 1.8)$ & 23.2 \\
14 & $1.04(\mathrm{~s})$ & 26.7 & $1.24(\mathrm{~s})$ & 31.1 \\
15 & $1.85(\mathrm{~s})$ & 22.2 & $1.77(\mathrm{~s})$ & 21.6 \\
\hline
\end{tabular}

NMR assignments are based on ${ }^{1} \mathrm{H}-{ }^{13} \mathrm{C}$ HSQC, $\mathrm{HMBC}$, and ${ }^{1} \mathrm{H}-{ }^{1} \mathrm{H}$ COSY contour maps; s: singlet; m: multiplet; d: doublet; dd: double doublets.

The ${ }^{13} \mathrm{C}$ spectrum showed a signal at $\delta_{\mathrm{C}} 203.9$ for carbonyl carbon and four methyl carbons at $\delta_{\mathrm{C}} 21.7(\mathrm{C}-12$ or $\mathrm{C}-13), \delta_{\mathrm{C}} 22.6\left(\mathrm{C}-12\right.$ or C-13), $\delta_{\mathrm{C}} 26.7(\mathrm{C}-14)$, and $\delta_{\mathrm{C}} 22.2(\mathrm{C}-15)$ as well as four methynic carbons at $\delta_{\mathrm{C}} 131.7(\mathrm{C}-1), \delta_{\mathrm{C}} 123(\mathrm{C}-2), \delta_{\mathrm{C}} 118(\mathrm{C}-3)$, and $\delta_{\mathrm{C}} 46.1$ (C-5). The chemical shifts $\delta_{\mathrm{C}} 123.0(\mathrm{C}-2), \delta_{\mathrm{C}} 118.0(\mathrm{C}-3), \delta_{\mathrm{C}} 22.6$ (C-12 or C-13), and $\delta_{\mathrm{C}} 22.2$ $(\mathrm{C}-15)$ are significantly different when compared to those reported in the literature for the synthetic compound 1 [19], $\delta_{\mathrm{C}} 118(\mathrm{C}-2), \delta_{\mathrm{C}} 123(\mathrm{C}-3), \delta_{\mathrm{C}} 22.2$ (C-12 or C-13), and $\delta_{\mathrm{C}} 22.6$ (C-15) [19]. With COSY, it was possible to correlate the couplings between the signals at $\delta_{\mathrm{H}} 5.33(\mathrm{~d}, J=9.4 \mathrm{~Hz}, \mathrm{H}-3)$ with $\delta_{\mathrm{H}} 5.76(\mathrm{~d}, J=9.4,5.3 \mathrm{~Hz}, \mathrm{H}-2)$ and $\delta_{\mathrm{H}} 2.66(\mathrm{dd}, J=10.6$, $4.8 \mathrm{~Hz}, \mathrm{H}-6)$ with $\delta_{\mathrm{H}} 2.24\left(\mathrm{~m}, \mathrm{H}-6^{\prime}\right)$ and $\delta_{\mathrm{H}} 2.00(\mathrm{dd}, J=10.6,4.8 \mathrm{~Hz}, \mathrm{H}-5)$. The HMBC spectrum analysis showed a correlation of C-7 $\left(\delta_{\mathrm{C}} 132.6\right)$ with $\mathrm{H}-6\left(\delta_{\mathrm{H}} 2.66\right), \mathrm{H}-6^{\prime}\left(\delta_{\mathrm{H}} 2.24\right)$, $\mathrm{H}-12$ or $\mathrm{H}-13\left(\delta_{\mathrm{H}} 1.79\right)$, and $\mathrm{H}-12$ or H-13 $\left(\delta_{\mathrm{H}} 1.94\right)$. The correlation of $\mathrm{C}-3\left(\delta_{\mathrm{C}} 118.0\right)$ with $\mathrm{H}-15\left(\delta_{\mathrm{H}} 1.85\right)$ and C-9 $\left(\delta_{\mathrm{C}} 53.4\right)$ with $\mathrm{H}-14\left(\delta_{\mathrm{H}} 1.04\right)$ confirmed the positions of the H-14 and $\mathrm{H}-15$ methyl groups. The position of the carbonyl group C-8 $\left(\delta_{\mathrm{C}} 203.9\right)$ correlated with the diastereotopic hydrogens $\mathrm{H}-6\left(\delta_{\mathrm{H}} 2.66\right)$ and $\mathrm{H}-6^{\prime}\left(\delta_{\mathrm{H}} 2.24\right)$ as well as $\mathrm{H}-9\left(\delta_{\mathrm{H}} 2.47\right)$ and H-9' $\left(\delta_{\mathrm{H}} 2.30\right)$.

Compound 2, also isolated as an oil, presented optical activity $[\alpha]_{D}^{20}-144^{\circ}(c$ 1.0, $\left.\mathrm{CHCl}_{3}\right)$ slightly above that found earlier in the first isolation, $[\alpha]_{D}^{20}-107^{\circ}\left(c 0.6, \mathrm{CHCl}_{3}\right)[8]$.

The ${ }^{1} \mathrm{H}$ and ${ }^{13} \mathrm{C}$ NMR signals are shown in Table 2. The ${ }^{1} \mathrm{H}$ NMR spectrum showed signals at $\delta_{\mathrm{H}} 2.40(\mathrm{~d}, J=15.0 \mathrm{~Hz})$ and $\delta_{\mathrm{H}} 2.19(\mathrm{~d}, J=13.7 \mathrm{~Hz})$ for the diastereotopic $\mathrm{H}-9$ and H-9' hydrogens. At $\delta_{\mathrm{H}} 6.02(\mathrm{~d}, J=7.7 \mathrm{~Hz})$ and at $\delta_{\mathrm{H}} 6.13(\mathrm{~s})$ are the signals corresponding to the methynic hydrogens $\mathrm{H}-2$ and $\mathrm{H}-3$. Four methyl groups were observed at the following displacements $\delta_{\mathrm{H}} 1.98(\mathrm{~d}, J=1.8 \mathrm{~Hz}, \mathrm{H}-12$ or $\mathrm{H}-13), \delta_{\mathrm{H}} 1.80(\mathrm{~s}, \mathrm{H}-12$ or $\mathrm{H}-13), \delta_{\mathrm{H}} 1.24$ (s, H-14), and $\delta_{\mathrm{H}} 1.77$ (s, H-15).

The ${ }^{13} \mathrm{C}$ spectrum showed $\delta_{\mathrm{C}} 202.7$ signal for carbonyl carbon. There were four methyl carbons at $\delta_{\mathrm{C}} 23.2(\mathrm{C}-12$ or $\mathrm{C}-13), \delta_{\mathrm{C}} 22.3\left(\mathrm{C}-12\right.$ or C-13), $\delta_{\mathrm{C}} 31.1(\mathrm{C}-14)$, and $\delta_{\mathrm{C}} 21.6(\mathrm{C}-15)$ and four methynic carbons at $\delta_{\mathrm{C}} 110.4(\mathrm{C}-1), \delta_{\mathrm{C}} 140.6(\mathrm{C}-2), \delta_{\mathrm{C}} 137.8(\mathrm{C}-3)$ and $\delta_{\mathrm{C}} 50.9(\mathrm{C}-5)$. With the analysis of the HMBC spectrum, it was possible to observe coupling via three 
bonds $\left({ }^{3} J_{\mathrm{CH}}\right)$ of $\mathrm{C}-3\left(\delta_{\mathrm{C}} 137.8\right)$ with $\mathrm{H}-5\left(\delta_{\mathrm{H}} 2.2\right)$ and $\mathrm{H}-15\left(\delta_{\mathrm{H}} 1.8\right)$ and coupling via two bonds $\left({ }^{3} J_{\mathrm{CH}}\right)$ of $\mathrm{C}-2\left(\delta_{\mathrm{C}} 140.6\right)$ with $\mathrm{H}-1\left(\delta_{\mathrm{H}} 4.4\right)$ and $\mathrm{H}-3\left(\delta_{\mathrm{H}} 6.1\right)$. These couplings infer the position of $\mathrm{C}-2$ and $\mathrm{C}-3$, which showed different displacements to those reported in the literature, $\mathrm{C}-2\left(\delta_{\mathrm{C}} 137.7\right)$ and $\mathrm{C}-3\left(\delta_{\mathrm{C}} 140.5\right)$ [8].

Compounds 1 and 2 were evaluated for their antioxidant potential using the DPPH assay, and the results are shown in Figure 2. It is noteworthy that compounds $\mathbf{1}$ and $\mathbf{2}$ present insignificant free-radical scavenging activity. Regarding the inhibition of lipoperoxidation in rat brain homogenate, the compounds $\mathbf{1}$ and $\mathbf{2}$ did not show inhibitory activity at $40 \mathrm{mg} / \mathrm{L}$. Thus, it is clear that compounds $\mathbf{1}$ and $\mathbf{2}$ do not present significant antioxidant activity through either single-electron transfer or hydrogen atom transfer (HAT) mechanisms. Garmus (2014) evaluated the antioxidant activity of the essential oil extracted from E. uniflora leaves and found that phenolic compounds found in the oil are mainly responsible for the antioxidant effect (determined using the DPPH assay). Similarly, Auricchio (2007) studied a hydroalcoholic extract from E. uniflora leaves and its inhibition of lipid oxidation in rat brain homogenate and found an $\mathrm{IC}_{50}$ of $35 \mathrm{mg} / \mathrm{L}$, which is different from the results obtained herein. Considering the data are obtained using two distinct mechanisms of antioxidant action, it is hypothesized that compounds $\mathbf{1}$ and $\mathbf{2}$ have no antioxidant potential $[20,21]$.

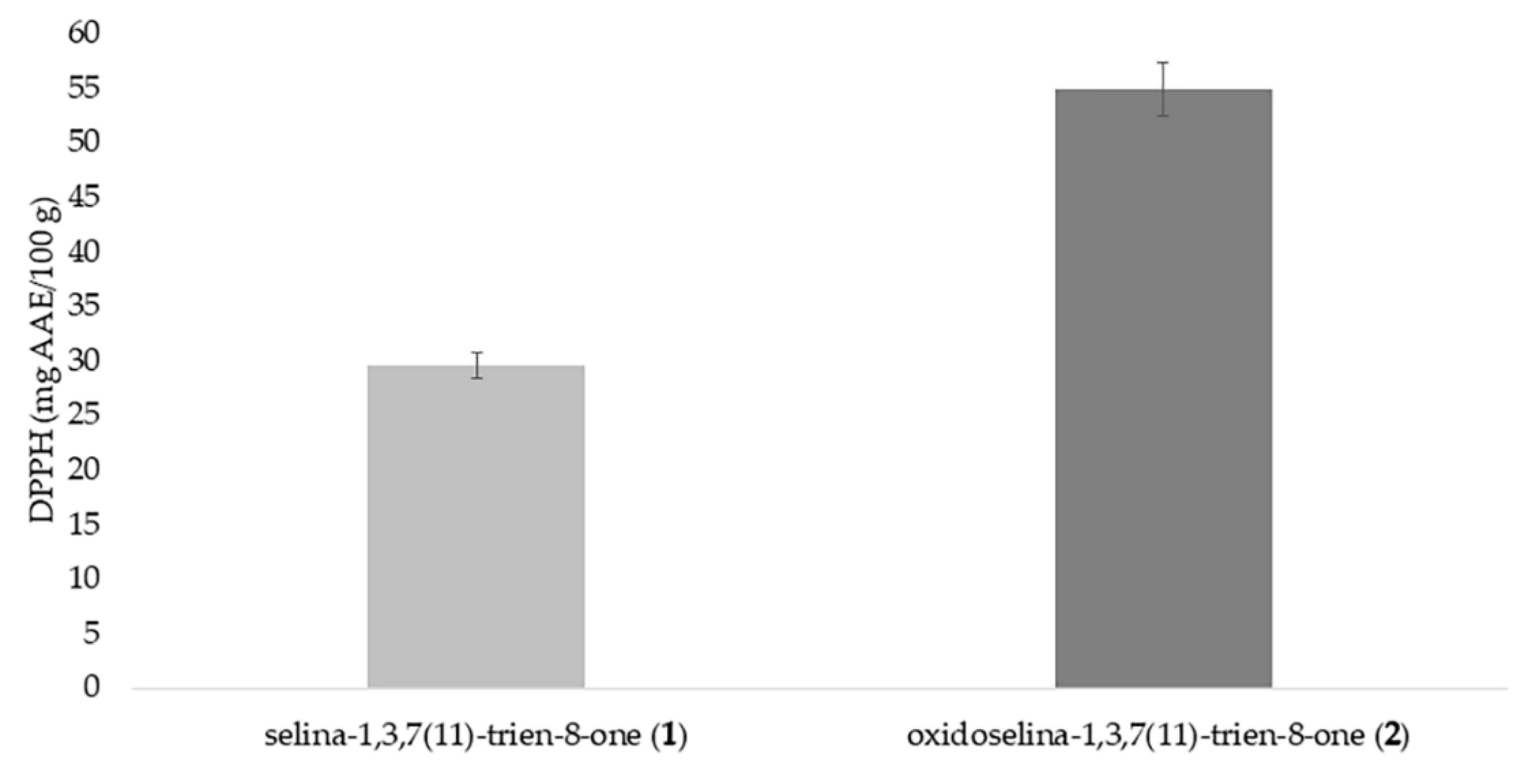

Figure 2. Antioxidant activity of compounds 1 and $\mathbf{2}$ in $\mathrm{mg}$ of ascorbic acid equivalent (AAE) per $100 \mathrm{~g}$ of material (AAE/100 g) as measured by the DPPH assay.

Regarding the cytotoxicity assay, the parameters $\mathrm{IC}_{50}, \mathrm{GI}_{50}$, and $\mathrm{LC}_{50}$ correspond to cell viability, antiproliferative effect, and cell death, respectively (Figure 3). All cell lines presented $\mathrm{IC}_{50}$ values $>500 \mu \mathrm{M}$, except 2 for HepG2 cells $\left(\mathrm{IC}_{50}=525.4 \mu \mathrm{M}\right)$. Following a similar approach, Figueiredo et al. (2019) reported that E. uniflora oil, with significant amounts of 1 and 2, decreased cell viability $\left(\mathrm{IC}_{50}=15.42 \mu \mathrm{g} / \mathrm{mL}\right)$ of MRC-5 normal cells [12]. Compounds 1 and 2 promoted, most notably, antiproliferative effects on IMR90 normal cells $\left(\mathrm{GI}_{50}=184.7\right.$ and $14.9 \mu \mathrm{M}$, respectively) when compared with $\mathrm{A} 549\left(\mathrm{GI}_{50}=590.8\right.$ and $359.3 \mu \mathrm{M}$, respectively) and HepG2 $\left(\mathrm{GI}_{50}=289.2\right.$ and $97.5 \mu \mathrm{M}$, respectively) cancer cells, indicating high cytotoxicity and low safety in in vitro studies. The lethal concentration $\left(\mathrm{LC}_{50}\right)$ for $\mathbf{1}$ and $\mathbf{2}$ was higher than $500 \mu \mathrm{M}$, indicating that it is necessary to use higher concentrations of these compounds to kill half of the cells. In the literature, it is recognized that phenolic compounds can act as either anti- or pro-oxidant agents [22] depending on their concentration, environmental $\mathrm{pH}$, and the presence of metals and oxygen [23]. 



Figure 3. Cell viability of human lung adenocarcinoma epithelial (A549), human hepatoma carcinoma (HepG2), and normal human lung fibroblast (IMR90) cells treated with compounds $\mathbf{1}$ and $\mathbf{2}$.

Herein, despite their antioxidant effect as pointed out by the DPPH assay, it was clear that both $\mathbf{1}$ and $\mathbf{2}$ compounds exerted pro-oxidant behavior (Figure 4) by inducing reactive oxygen species (ROS) generation in non-cancer (IMR90) and malignant (A549) cells, which explains their cytotoxicity observed in cell viability assay. It is known that if ROS levels increase dramatically to toxic concentrations, the JNK (c-Jun NH2-terminal kinases) pathway can be activated, resulting in apoptosis and cell death [22]. By contrast, Sobeh (2019) reported that the methanolic extract of E. uniflora leaves present noticeable antioxidant properties by reducing the intracellular ROS levels and by increasing the reduced glutathione (GSH) content in HaCaT cells [24]. This disagreement may be explained by the chemical profile of a crude extract compared to the isolated compounds $\mathbf{1}$ and $\mathbf{2}$. In this case, the antioxidant effect may have occurred due to the synergistic effects between the bioactive compounds the crude extract, while the oxidative activity shown herein was related to the individual abilities of compounds $\mathbf{1}$ and $\mathbf{2}$. Indeed, our results highlight the high cytotoxicity of compounds $\mathbf{1}$ and $\mathbf{2}$, acting in a more intense way against IMR90 
normal cells than cancer cells (A549 and HepG2) because of their pro-oxidant behavior, as observed in the ROS generation assay.
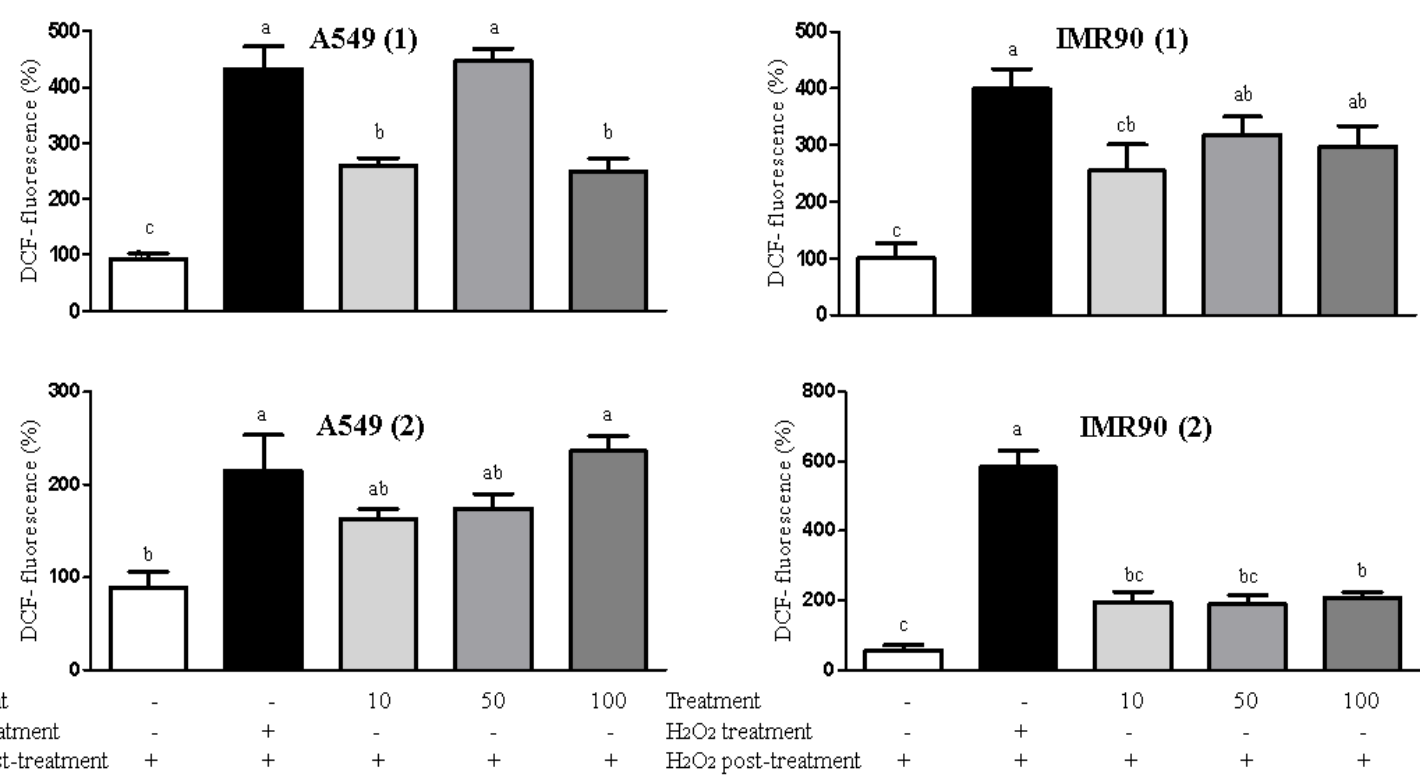

Figure 4. Results for intracellular ROS in A549 and IMR90 cells treated with 1 and $\mathbf{2}(10,50$ and $100 \mu \mathrm{M})$ as measured by spectrofluorometry. The data were analyzed by one-way ANOVA and quantitative data are expressed by mean \pm standard deviation. * Different letters in the columns mean statistical difference.

The antioxidant activity measured by chemical and biological assays, together with the cell-based antioxidant activity measurement, clearly indicates that 1 and $\mathbf{2}$ cannot be considered antioxidant agents. Data obtained using chemical antioxidant activity (inhibition of lipid peroxidation and DPPH assay) and the induced ROS generation show that 1 and $\mathbf{2}$ are not able to scavenge free radicals (DPPH, peroxyl and hydroxyl radicals) and decrease intracellular ROS generation. Thus, it is clear that any prospect of compounds 1 and $\mathbf{2}$ having antioxidant action is very limited. In addition, taken all together, results show pro-oxidative effects and cytotoxicity in relation to normal human cells. This poses a toxicological concern for both substances, and the data generated here can be used as a basis for other biological assays that may encompass antioxidant and cytotoxic studies of the compounds [25].

\section{Materials and Methods}

\subsection{Plant Material}

Eugenia uniflora L. (Myrtaceae) leaves were collected in the Uvaranas Campus, Ponta Grossa State University, Ponta Grossa-PR, Brazil, in the location -25.091824 and -50.102573, and an exsiccate was deposited at the HUPG (Herbarium University of Ponta Grossa) under number 22452.

\subsection{Essential Oil Extraction and GC-MS Analysis}

Three portions of approximately $300 \mathrm{~g}$ of ground dried leaves were extracted for $2.5 \mathrm{~h}$ in a steam distillation glass distiller. The oil samples were pooled in ethyl ether, dried over anhydrous $\mathrm{Na}_{2} \mathrm{SO}_{4}$, filtered, and evaporated under vacuum and at low temperature, yielding $7.56 \mathrm{~g}(0.84 \% w / w)$ based on dry weight.

For the oil analyses by GC-MS (Shimadzu GCMS-QP2010 Plus Gas Chromatograph), a non-polar Rtx-5MS column $(30 \mathrm{~m} \times 0.25 \mathrm{~mm} \times 0.25 \mu \mathrm{m})$ and the following analytical conditions were used: split ratio of $1 / 20,250^{\circ} \mathrm{C}$ for the injector, $250^{\circ} \mathrm{C}$ for the ion source, and $280{ }^{\circ} \mathrm{C}$ for the interface. The oven temperature was programmed to $60^{\circ} \mathrm{C}$ for the first $5 \mathrm{~min}$, increasing at a rate of $3{ }^{\circ} \mathrm{C} / \mathrm{min}$ to reach the final temperature of $240{ }^{\circ} \mathrm{C}$. 
The components were identified based on the relative retention indices calculated using a series of n-alkanes (C8-C19) and the mass spectra from the apparatus database, followed by comparison with the published data $[8,17,18]$.

\subsection{Isolation and Structure Identification of Compounds}

The essential oil sample $(7.0 \mathrm{~g})$ was fractionated on a hexane packed silica gel 60 (240-400 mesh, Merck) column chromatography eluted with hexane/ethyl acetate mixtures in a gradient of increasing polarity. The two main components of the oil were isolated in various fractions $(\mathbf{1}, 0.6 \mathrm{~g} ; \mathbf{2}, 0.4 \mathrm{~g})$ and presented as single well-defined spots in thin layer chromatography (Macharey-Nagel $60 \mathrm{G}_{254} 0.2 \mathrm{~mm}$ plates) first observed under $254 \mathrm{~nm} \mathrm{UV}$ light and then sprayed with $\mathrm{H}_{2} \mathrm{SO}_{4} / \mathrm{MeOH}(1: 1)$ and heated on a hot plate.

Structural identification of the compounds was carried out by spectroscopic analysis. Optical rotation measurements were determined on a Perkin-Elmer 343 polarimeter. UV spectra (in $\mathrm{CHCl}_{3}$ ) were measured on a Varian Cary 50 spectrophotometer. ${ }^{1} \mathrm{H}$ and ${ }^{13} \mathrm{C}$ NMR spectra were obtained on a Bruker Ascend $400 \mathrm{MHz}$ spectrometer using $\mathrm{CDCl}_{3}$ and tetramethylsilane as internal reference. Signal assignments in NMR spectra were made by combining the 1D and 2D techniques, correlation spectroscopy (COSY), heteronuclear single quantum correlation (HSQC), and heteronuclear multiple bond correlation (HMBC) and by comparison with data published in the literature.

1: Oil; $[\alpha]_{D}^{20}-8^{\circ}\left(c 1.0, \mathrm{CHCl}_{3}\right)$; UV $\left(\mathrm{CHCl}_{3}\right) \lambda_{\max }: 250 \mathrm{~nm} ;{ }^{1} \mathrm{H} \mathrm{NMR}\left(400 \mathrm{MHz}, \mathrm{CDCl}_{3}\right)$, see Table $2 ;{ }^{13} \mathrm{C}$ NMR $\left(100 \mathrm{MHz}, \mathrm{CDCl}_{3}\right)$, see Table 2 ; $\mathrm{HMBC}$ (selected correlations) $\mathrm{C} 1 \rightarrow \mathrm{H} 3$, $\mathrm{H9} / \mathrm{H} 9$ ', H14; C2 $\rightarrow \mathrm{H} 15 ; \mathrm{C} 3 \rightarrow \mathrm{H} 2, \mathrm{H} 1, \mathrm{H} 15 ; \mathrm{C} 4 \rightarrow \mathrm{H} 15, \mathrm{H} 2 ; \mathrm{C} 5 \rightarrow \mathrm{H} 3, \mathrm{H} 6 ; \mathrm{C} 6 \rightarrow \mathrm{H} 5, \mathrm{H} 15$; $\mathrm{C} 7 \rightarrow \mathrm{H} 13, \mathrm{H} 12 ; \mathrm{C} 10 \rightarrow \mathrm{H} 14, \mathrm{H} 2, \mathrm{H} 1 ; \mathrm{C} 14 \rightarrow \mathrm{H} 9 / \mathrm{H}^{\prime} ; \mathrm{C} 15 \rightarrow \mathrm{H} 3$.

2: Oil; $[\alpha]_{D}^{20}-144^{\circ}$ (c 1.0, $\left.\mathrm{CHCl}_{3}\right)$; UV $\left(\mathrm{CHCl}_{3}\right) \lambda_{\max }: 250 \mathrm{~nm} ;{ }^{1} \mathrm{H} \mathrm{NMR}(400 \mathrm{MHz}$, $\left.\mathrm{CDCl}_{3}\right)$, see Table $2 ;{ }^{13} \mathrm{C}$ NMR $\left(100 \mathrm{MHz}, \mathrm{CDCl}_{3}\right)$, see Table 2; HMBC (selected correlations) $\mathrm{C} 1 \rightarrow \mathrm{H} 2, \mathrm{H} 9 / \mathrm{H}^{\prime}, \mathrm{H} 14 ; \mathrm{C} 2 \rightarrow \mathrm{H} 3, \mathrm{H} 1 ; \mathrm{C} 3 \rightarrow \mathrm{H} 15, \mathrm{H} 5, \mathrm{H} 2 ; \mathrm{C} 4 \rightarrow \mathrm{H} 3, \mathrm{H} 15 ; \mathrm{C} 5 \rightarrow \mathrm{H} 3, \mathrm{H} 6$; $\mathrm{C} 7 \rightarrow \mathrm{H} 12, \mathrm{H} 13 ; \mathrm{C} 10 \rightarrow \mathrm{H} 14, \mathrm{H} 2 ; \mathrm{C} 14 \rightarrow \mathrm{H} 9 / \mathrm{H}^{\prime} ; \mathrm{C} 15 \rightarrow \mathrm{H} 3$.

\subsection{Chemical and Biological Antioxidant Activities}

The free-radical scavenging activity of $\mathbf{1}$ and $\mathbf{2}$ in relation to the 2,2-diphenyl-1picrylhydrazyl (DPPH) radical was measured using the colorimetric method described by Brand-Williams (1995), and the results are expressed in mg of ascorbic acid equivalent per $100 \mathrm{~g}$ of material (AAE/100 g) [26]. To evaluate the capacity of hydrogen atom transfer (HAT) of the isolated compounds, male Wistar rat brain homogenate was used as substrate for the production of thiobarbituric acid reactive substances (TBARS) produced by $\mathrm{Fe}^{2+}$ induced oxidation undertaken at $37^{\circ} \mathrm{C}$, following the experimental conditions described elsewhere [27]. The inhibition of lipid peroxidation was expressed as \% of inhibition. The animal protocol was approved by the Ethics Committee (UEPG, protocol 47/2017).

\subsection{Cytotoxicity Assay}

The in vitro cytotoxic effect of $\mathbf{1}$ and $\mathbf{2}$ compounds were analyzed in relation to A549 (lung adenocarcinoma epithelial cells-BCRJ code: 0033), HepG2 (human hepatoma carcinoma cells-BCRJ code: 0291), and IMR90 (human lung fibroblast-BCRJ code: 0118) cell lines using MTT (3-(4,5-dimethylthiazol-2-yl)-2,5-diphenyl tetrazolium bromide) (SigmaAldrich, COD-M5655) assay [28]. All cell lines were maintained in Dulbecco's Modified Eagle's Medium/Nutrient Mixture F-12 Ham (Sigma-Aldrich, COD_D8900), with added 10\% fetal bovine serum (FBS, Gibco, COD-16000044) and $100 \mathrm{IU}$ penicillin/100 $\mu$ g streptomycin (Sigma-Aldrich, COD-P4333). The cell lines were grown in a humidified incubator at $37{ }^{\circ} \mathrm{C}$ containing $5 \% \mathrm{CO}_{2}$. Briefly, the cells were seeded into 96-well plates at a density of $1 \times 10^{4}$ cells/well (HepG2 and A549), $5 \times 10^{3}$ cells/well (IMR90), $100 \mu \mathrm{L} /$ well, and after $24 \mathrm{~h}$, the cells were treated with $100 \mu \mathrm{L}$ of serial concentrations $(10-500 \mu \mathrm{M})$ of compounds 1 and 2 for $48 \mathrm{~h}$. The stock solution of extracts contained 5\% of dimethyl sulfoxide (DMSO) at a final concentration of $0.2 \%$ in cell medium for all in vitro assays. The $\mathrm{IC}_{50}, \mathrm{GI}_{50}$, and $\mathrm{LC}_{50}$ parameters were performed in accordance with the method described 
by do Carmo (2018) [22], in which $\mathrm{IC}_{50}$ is the concentration of the agent that inhibits growth by $50 \%$, calculated as $(\mathrm{T} / \mathrm{C}) \times 100=50$, where $\mathrm{T}=$ number of cells at time $\mathrm{t}$ of treatment; $\mathrm{C}=$ control cells at time $\mathrm{t}$ of treatment; $\mathrm{GI}_{50}$ is the concentration of the agent that inhibits growth by $50 \%$ relative to untreated cells, calculated as $((\mathrm{T}-\mathrm{T} 0) /(\mathrm{C}-\mathrm{T} 0)) \times 100=$ 50 , where $\mathrm{T}$ and $\mathrm{C}$ are the number of treated and control cells, respectively, at time $t$ of treatment, and T > T0 where T0 is the number of cells at time zero; $\mathrm{LC}_{50}$ is the concentration of the agent that results in a net loss of $50 \%$ cells relative to the number at the start of treatment, calculated as $((\mathrm{T}-\mathrm{T} 0) / \mathrm{T} 0) \times 100=-50$, where $\mathrm{T}<\mathrm{T} 0$. The experiments were conducted in quadruplicate on three different days to assure the reproducibility of the generated data.

\subsection{Intracellular Reactive Oxygen Species (ROS) Measurement}

In order to assess the in vitro antioxidant/oxidant potential of $\mathbf{1}$ and $\mathbf{2}$, intracellular ROS generation was measured using a fluorescence technique as described by Carmo (2019) [29]. Briefly, A549 cancer cells $\left(6 \times 10^{4} /\right.$ well $)$ and IMR90 normal cells $\left(2 \times 10^{4} /\right.$ well $)$ were exposed to concentrations of 10,50 , and $100 \mu \mathrm{g} / \mathrm{mL}$ of $\mathbf{1}$ and 2 compounds, culture medium (negative control), and $15 \mu \mathrm{mol} / \mathrm{L} \mathrm{H}_{2} \mathrm{O}_{2}$ (positive control), for $1 \mathrm{~h}$ in DCFH-DA solution $(25 \mathrm{mmol} / \mathrm{L})$, at $37^{\circ} \mathrm{C}$ and $5 \% \mathrm{CO}_{2}$. Subsequently, cells were washed with PBS and a $\mathrm{H}_{2} \mathrm{O}_{2}$ solution $(15 \mu \mathrm{mol} / \mathrm{L})$ added for recording of fluorescence. Intracellular fluorescence intensity of cells was measured at an excitation wavelength of $485 \mathrm{~nm}$ and at an emission wavelength of $538 \mathrm{~nm}$ [29]. The assays were performed in quadruplicate on three different days.

\subsection{Statistical Analysis}

The significance for intracellular ROS measurement was defined by one-way analysis of variance followed by Tukey's test. Analysis on sigmoidal dose-response for cytotoxicity was performed using nonlinear regression for curve fitting.

\section{Conclusions}

We obtained and confirmed the chemical structures of $\mathbf{1}$ and $\mathbf{2}$ here and also provide a simple method for their isolation. Our results for structure analyses and cytotoxicity confirm the importance of establishing more knowledge about the volatile metabolites of Eugenia uniflora.

Supplementary Materials: The following are available online. Figure S1. ${ }^{1} \mathrm{H}$ NMR $(400 \mathrm{MHz})$ spectrum of compound $\mathbf{1}$ in $\mathrm{CDCl}_{3}$. Figure S2. ${ }^{13} \mathrm{C}$ NMR (100 MHz) spectrum of compound 1 in $\mathrm{CDCl}_{3}$. Figure S3. ${ }^{1} \mathrm{H}$ NMR (400 MHz) spectrum of compound 2 in $\mathrm{CDCl}_{3}$. Figure S4. ${ }^{13} \mathrm{C} \mathrm{NMR}$ (100 MHz) spectrum of compound 2 in $\mathrm{CDCl}_{3}$. Figure S5. HSQC NMR (400 MHz) spectrum of compound 2 in $\mathrm{CDCl}_{3}$. Figure S6. $\mathrm{HMBC} \mathrm{NMR}(400 \mathrm{MHz})$ spectrum of compound 2 in $\mathrm{CDCl}_{3}$. Figure S7. COSY NMR (400 MHz) spectrum of compound 2 in $\mathrm{CDCl}_{3}$. Figure S8. HMBC NMR (400 MHz) spectrum of compound 1 in $\mathrm{CDCl}_{3}$. Figure S9. HSQC NMR (400 MHz) spectrum of compound 1 in $\mathrm{CDCl}_{3}$. Figure S10. COSY NMR (400 MHz) spectrum of compound 1 in $\mathrm{CDCl}_{3}$. Figure S11. Chromatogram of the essential oil from leaves of E. uniflora using GC-MS analysis.

Author Contributions: Organization of the study, J.A. and D.S.N.; plant material and essential oil extraction, V.M.S., C.G.M. and D.S.N.; isolation and structure identification of compounds, J.A., M.F.M.P., M.V.L.R.A. and D.R.S.; antioxidant and cytotoxicity assay, D.G., J.S.S., M.A.V.d.C. and L.A.; writing-review and editing, J.A., D.S.N., D.G. and L.A. All authors have read and agreed to the published version of the manuscript.

Funding: This research received no external funding.

Institutional Review Board Statement: The animal protocol was approved by the Ethics Committee (UEPG, protocol 47/2017).

Informed Consent Statement: Not applicable.

Data Availability Statement: Data is contained within the article or supplementary material. 
Acknowledgments: M.F.M.P. and V.M.S. thank the Fundação Araucária for IC fellowships.

Conflicts of Interest: The authors declare no conflict of interest.

Sample Availability: Samples of the compounds are not available from the authors.

\section{References}

1. Van der Merwe, M.M.; Van Wyk, A.E.; Botha, A.M. Molecular phylogenetic analysis of Eugenia L. (Myrtaceae), with emphasis on Southern African taxa. Plant Syst. Evol. 2005, 251, 21-34. [CrossRef]

2. Wilson, P.G. Conspectus of the genus Eugenia (Myrtaceae). Gard. Bull. Singap. 2009, 60, 399-410.

3. Gallucci, S.; Placeres-Neto, A.; Porto, C.; Barbizan, D.; Costa, I.; Marques, K.; Benevides, P.; Figueiredo, R. Essential oil of Eugenia uniflora L.: An industrial perfumery approach. J. Essent. Oil Res. 2008, 22, 176-179. [CrossRef]

4. Rovedder, A.P.M.; Piazza, E.M.; Thomas, P.A.; Felker, R.M.; Hummel, R.B.; de Farias, J.A. Chemical composition and antioxidant activity of essential oil and organic extracts of Premna integrifolia Linn. Braz. Arch. Biol. Technol. 2016, 59 , e16160223.

5. Mesquita, P.R.R.; Nunes, E.C.; dos Santos, F.N.; Bastos, L.P.; Costa, M.A.P.C.M.; Rodrigues, F.; de Andrade, J.B. Discrimination of Eugenia uniflora L. biotypes based on volatile compounds in leaves using HS-SPME/GC-MS and chemometric analysis. Microchem. J. 2017, 130, 79-87. [CrossRef]

6. Mazine, F.F.; Valdemarin, K.S.; Bünger, M.; Faria, J.E.Q.; Fernandes, T.; Giaretta, A.; Santana, K.C.; Sobral, M.; Souza, M.A.D. Eugenia in Flora do Brasil 2020 em Construção. Jardim Botânico do Rio de Janeiro. Available online: http:/ / floradobrasil.jbrj.gov. br/reflora/floradobrasil/FB10560 (accessed on 14 January 2021).

7. Rücker, G.; Silva, G.; Bauer, L.; Schikarski, M. New constituents of Stenocalyx michelii. Planta Med. 1977, 31, 322-327. [CrossRef]

8. Weyerstahl, P.; Marschall-Weyerstahl, H.; Christiansen, C.; Oguntimein, B.; Adeoye, A. Volatile constituents of Eugenia uniflora leaf oil. Planta Med. 1988, 54, 546-549. [CrossRef]

9. Morais, S.M.; Craveiro, A.A.; Machado, M.I.L.; Alencar, J.W.; Matos, F.J.A. Essential oils from neotropical Myrtaceae: Chemical diversity and biological properties. J. Essent. Oil Res. 1996, 8, 449-451.

10. Costa, D.P.; Alves Filho, E.G.; Silva, L.M.A.; Santos, S.C.; Passos, X.S.; Silva, M.R.R.; Seraphin, J.C.; Ferri, P.H. Influence of fruit biotypes on the chemical composition and antifungal activity of the essential oils of Eugenia uniflora leaves. J. Braz. Chem. Soc. 2010, 21, 851-858. [CrossRef]

11. Maia, J.G.S.; Andrade, E.H.A.; Silva, M.H.L.; Zoghbi, M.G.B. A new chemotype of Eugenia uniflora L. from North Brazil. J. Essent. Oil Res. 1999, 11, 727-729. [CrossRef]

12. Figueiredo, P.L.B.; Pinto, L.C.; da Costa, J.S.; da Silva, A.R.C.; Mourão, R.H.V.; Montenegro, R.C.; da Silva, J.K.R.; Maia, J.G.S. Composition, antioxidant capacity and cytotoxic activity of Eugenia uniflora L. chemotype-oils from the Amazon. J. Ethnopharm. 2019, 232, 30-38. [CrossRef] [PubMed]

13. Dos Santos, J.F.S.; Rocha, J.E.; Bezerra, C.F.; do Nascimento Silva, M.K.; de Matos, Y.M.L.S.; de Freitas, T.S.; dos Santos, A.T.L.; da Cruz, R.P.; Machado, A.J.T.; Rodrigues, T.H.S.; et al. Chemical composition, antifungal activity and potential anti-virulence evaluation of the Eugenia uniflora essential oil against Candida spp. Food Chem. 2018, 261, 233-239. [CrossRef] [PubMed]

14. Victoria, F.N.; Anversa, R.G.; Savegnago, L.; Lenardão, E.J. Essential oils of E. uniflora leaves protect liver injury induced by acetaminophen. Food Biosci. 2013, 4, 50-57. [CrossRef]

15. Victoria, F.N.; de Siqueira Brahm, A.; Savegnago, L.; Lenardão, E.J. Essential oil of the leaves of Eugenia uniflora L.: Antioxidant and antimicrobial properties. Neurosci. Lett. 2013, 544, 105. [CrossRef] [PubMed]

16. Ogunwande, I.A.; Olawore, N.O.; Ekundayo, O.; Walker, T.M.; Schmidt, J.M.; Setzer, W.N. Eugenia uniflora: Potential uses as a bioactive plant. Int. J. Aromather. 2005, 15, 147-152. [CrossRef]

17. Adams, R.P. Identification of Essential Oil Components by Gas Chromatography/Mass Spectroscopy, 4th ed.; Allured Publishing Corporation: Carol Stream, IL, USA, 2009.

18. Peixoto, C.A.; Oliveira, A.L.; Cabral, F.A. Composition of supercritical carbon dioxide extracts of pitanga (Eugenia uniflora L.) leaves. J. Food Process Eng. 2010, 33, 848-860.

19. Kanazawa, A.; Patin, A.; Greene, A.E. Efficient, highly enantioselective synthesis of selina- 1,3,7(11)-trien-8-one, a major component of the essential oil of Eugenia uniflora. J. Nat. Prod. 2000, 63, 1292-1294. [CrossRef]

20. Garmus, T.T.; Paviani, L.C.; Queiroga, C.L.; Magalhães, P.M.; Cabral, F.A. Extraction of phenolic compounds from pitanga (Eugenia uniflora L.) leaves by sequential extraction in fixed bed extractor using supercritical $\mathrm{CO}_{2}$, ethanol and water as solvents. J. Supercrit. Fluids 2014, 86, 4-14. [CrossRef]

21. Auricchio, M.T.; Adriana Bugno, A.; Barros, S.B.; Bacchi, E.M. Atividades antimicrobiana e antioxidante e toxicidade de Eugenia uniflora. Lat. Am. J. Pharm. 2007, 26, 76-81.

22. Do Carmo, M.A.V.; Pressete, C.G.; Marques, M.B.; Granato, D.; Azevedo, L. Polyphenols as potential antiproliferative agents: Scientific trends. Curr. Opin. Food Sci. 2018, 24, 26-35. [CrossRef]

23. Eghbaliferiz, S.; Iranshahi, M. Prooxidant activity of polyphenols, flavonoids, anthocyanins and carotenoids: Updated review of mechanisms and catalyzing metals. Phytother. Res. 2016, 30, 1379-1391. [CrossRef] [PubMed]

24. Sobeh, M.; El-Raey, M.; Rezq, S.; Abdelfattah, M.A.O.; Petruk, G.; Osman, S.; Wink, M. Chemical profiling of secondary metabolites of Eugenia uniflora and their antioxidant, anti-inflammatory, pain killing and anti-diabetic activities: A comprehensive approach. J. Ethnopharm. 2019, 240, 111939. [CrossRef] [PubMed] 
25. Pellegrini, N.; Vitaglione, P.; Granato, D.; Vogliano, V. Twenty-five years of total antioxidant capacity measurement of foods and biological fluids: Merits and limitations. J. Sci. Food Agric. 2018. [CrossRef] [PubMed]

26. Brand-Williams, W.; Cuvelier, M.E.; Berset, C.L.W.T. Use of a free radical method to evaluate antioxidant activity. Food Sci. Technol. Leb. 1995, 28, 25-30. [CrossRef]

27. Fidelis, M.; Santos, J.S.; Escher, G.B.; do Carmo, M.A.V.; Azevedo, L.; da Silva, M.C.; Putnik, P.; Granato, D. In vitro antioxidant and antihypertensive compounds from camu-camu (Myrciaria dubia McVaugh, Myrtaceae) seed coat: A multivariate structure-activity study. Food Chem. Toxicol. 2018, 120, 479-490. [CrossRef] [PubMed]

28. Zhang, L.; Santos, J.S.; Cruz, T.M.; Marques, M.B.; do Carmo, M.A.V.; Azevedo, L.; Wang, Y.; Granato, D. Multivariate effects of Chinese keemun black tea grades (Camellia sinensis var. sinensis) on the phenolic composition, antioxidant, antihemolytic and cytotoxic/cytoprotection activities. Food Res. Int. 2019, 125, 108516. [CrossRef]

29. Do Carmo, M.A.V.; Fidelis, M.; Pressete, C.G.; Marques, M.B.; Castro-Gamero, A.M.; Myoda, T.; Azevedo, L. Hydroalcoholic Myrciaria dubia (camu-camu) seed extracts prevent chromosome damage and act as antioxidant and cytotoxic agents. Food Res. Int. 2019, 125, 108551. [CrossRef] 